\title{
Venous Injury
}

National Cancer Institute

\section{Source}

National Cancer Institute. Venous Injury. NCI Thesaurus. Code C78711.

Damage to a vein from traumatic or pathologic processes. 